\title{
Pervasive skills and accounting graduates' employment prospects: Are South African employers calling for pervasive skills when recruiting?
}

\section{Favourite Mhlongo}

Accounting Education, School of Education, University of KwaZulu-Natal, Durban, South Africa mhlongof1@ukzn.ac.za

https://orcid.org/0000-0002-4951-805X

(Received: 20 January 2020; accepted: 15 September 2020)

\section{Abstract}

In response to the pressures of globalisation and information technology, accounting practitioners are generally expected to demonstrate greater capacity in pervasive or generic skills. Universities offering accounting programmes in South Africa have revised accounting degree curricula to provide an added focus on pervasive skills. However, it remains unclear whether such interventions strengthen the position of accounting graduates in the job-seeking process, nor is it clear which of the many possible pervasive skills are relevant for employers. Through content analysis of online advertised accounting vacancies, this quantitative study sought to investigate whether employers do call for pervasive skills when recruiting accounting graduates and, if so, which of these skills are most sought after. The findings indicate that, indeed, employers generally specified pervasive skills, and that oral and written communication and critical thinking were the most sought-after of these skills for accounting-related employment in South Africa.

Keywords: pervasive skills, work-readiness, accounting education, professional skills, graduate employability

\section{Introduction}

Higher education, perceived through a social lens, is provided within social and economic contexts to communities, and it should be designed to improve job prospects for university students. Preparing students for the world of work is one of the aims of higher education (Jackson, 2013), and is achieved by ensuring that the knowledge and skills transferred meet the demands of employers. Research studies, however, seem to paint a bleak picture about higher education, with some scholars having argued that it fails to transform parallel with the changes taking place in societies (Maclean \& Ordonez, 2007), and that it fails to guarantee employment to graduates. This has raised concerns and calls for an urgent transformation of university education, globally, to keep up with the demands of the ever-evolving 
communities and workplace. Universities, globally, are expected to keep their curricula up to date and in line with the changing needs of employers and a competitive labour market.

In South Africa, as in other developing countries, many university students seek employment upon graduating with a first university degree. This may be due to the heightened cost of higher education - many students from disadvantaged backgrounds incur massive debts in student loans, yet are expected to provide financially for their families soon after graduation. Therefore, the pressure to secure employment and to improve earning potential immediately after graduating with a bachelor's degree becomes paramount for many students in those circumstances. Accounting is one of the specialisations that students select for its perceived ability to secure immediate employment for its graduates. The field has gained popularity with school leavers over the past few years, in spite of its being perceived by some as an uninteresting, tedious, less-creative occupation that is meant for the conservative (Jeacle, 2008). The growth in the number of accounting students, coupled with the high rate of unemployment in South Africa, has resulted in jobs in this field being heavily contested.

Research has shown that employers prefer skilled accounting graduates with pervasive skills who are ready to add value in the workplace (Aman \& Sitotaw, 2014; Seetha, 2014; Singh et al. 2014). "Pervasive skills" is a term used in the professional body, South African Institute of Chartered Accountants (SAICA)'s, Competency Framework (2009) to refer to what would usually be referred to as generic or soft skills. Accounting literature across the globe has used various terms when referring to pervasive skills and qualities; these include generic skills (Abayadeera \& Watty, 2014; Boyce et al., 2001; Bunney et al., 2015), professional skills (International Federation of Accountants, 2014), employability skills (Altrawneh, 2016; Stoner \& Milner, 2010; Tan \& Fawzi, 2017), soft skills (de Villiers, 2010; Ramlall \& Ramlall, 2014), and many others. Hence, there is no single definition for pervasive skills given that most definitions are discipline or context specific. This study subscribes to a definition of pervasive skills as being the "interpersonal, human, people or behavioural skills needed to apply technical skills and knowledge in the workplace" (Weber et al., 2009, p. 356), which is consistent with the SAICA (2009) Competency Framework and accounting literature.

The SAICA 2009 Competency Framework indicated that "entry-level chartered accountants are required to display the highest proficiency in pervasive skills" (as quoted in SAICA, 2010, p. 19) and identified skills such as ethical behaviour, professionalism, personal attributes, and professional skills that aspiring chartered accountants should possess prior to entry into the profession (SAICA, 2017). However, employers have raised concerns about the employment readiness of accounting graduates, linked to their lack of pervasive skills (Kunz \& de Jager, 2019; Schulz, 2008); a gap between what they prefer and what graduates possess, suggesting a misalignment. Evidence has suggested that students face challenges with applying theoretical knowledge obtained at university to practical workplace scenarios (Tempone et al., 2012), and are unable to adapt to the workplace because of their poor command of pervasive skills (Wye \& Lim, 2009). Some have attributed these challenges to the inability of accounting education to produce graduates who are ready for professional 
practice (Hakim, 2016; Mohamed \& Lashine, 2003). Consequently, accounting education has been the subject of many scholarly debates, which have resulted in studies that investigate its abilities and deficiencies in terms of producing graduates who meet the expectations of employers (Cory \& Pruske, 2012). The call for the prioritisation of pervasive skills in the accounting profession has thus attracted much activity for universities offering accredited accounting programmes (Jackson \& Chapman, 2012). Pervasive skills may serve as "distinguishing factors" during the job-seeking process and be associated with life and employment success (Gibb, 2014). However, because there many pervasive skills that could be important to an accounting graduate, it may prove impossible to be fully competent in all; thus, skills that make graduates marketable to prospective employers ought to be known so that they are prioritised in the curricula.

Local research studies on this topic have focused largely on the views of academics about their awareness of, and responsibility for, instilling pervasive skills (Barac \& du Plessis, 2014; Keevy, 2020; Strauss-Keevy, 2014; Viviers, 2016a), on students' perceptions of pervasive skills development (Kirstein, 2017), and on teaching and learning for pervasive skills development (Keevy, 2016; Strauss-Keevy, 2012; van Oordt \& Sullivan, 2019; Viviers et al., 2016). However, the actual pervasive skills that employers call for when recruiting accounting graduates have not been clarified in the South African context. This study, part of a broader study (my doctoral study, in progress) that focuses on the role of pervasive skills in the academic and professional preparation of graduate accountants, sought to fill this gap. An investigation was undertaken to determine whether employers of accounting graduates were indeed calling for pervasive skills (in addition to technical skills) in their advertised accounting vacancies and, if so, which skills were most sought as well as the terminology used to refer to these skills. Indicating or itemising the pervasive skills expected of future accounting employees in advertised vacancies is an effective way to communicate the requirements of employers to job-seekers. For the study, 15 pervasive skills were tested for appearance in accounting vacancies: Self-management, time management, self-discipline, independence, oral communication, written communication, critical thinking, decision making, computer application, teamwork, stress management, problem solving, lifelong learning, responsibility, numeracy. These skills were selected because they are consistent with the pervasive (or professional) skills prescribed by major accounting professional bodies in South Africa and are expected to be integrated into accounting curricula.

Thus, the objective of this study was to determine the pervasive skills-valuable inputs in the production of economic value as per Becker's (1964) human capital theory (HCT) - that employers of accounting graduates call for when recruiting accounting employees. The study was guided by the research question: "To what extent do employers emphasise pervasive skills in advertisements for accounting professionals, and which skills do they specify?"

\section{Literature review}

In South Africa, three stakeholders determine the attributes of accounting graduates: professional bodies, academic programmes (accounting education), and employers. 
Professional bodies are responsible for determining the desired skills, competencies, and attributes expected of accounting graduates through the accreditation process of accounting programmes. Accounting education is responsible for ensuring that the desired attributes, competencies, and skills are instilled through the curriculum. Employers, on the other hand, indicate their preferred skills, competencies, and attributes in job advertisements for accounting positions (Dunbar et al., 2016). Many universities in South Africa offer professional accounting degrees, most of which are accredited with the leading professional body, SAICA.

Students enrolled in accredited accounting programmes in South Africa can graduate with a degree after three years of study. Those seeking to qualify as chartered accountants further their studies with an additional year of the postgraduate Certificate in the Theory of Accounting (CTA), a qualification that improves their prospects of securing a three-year professional training contract with an accounting firm. Various employment options are available to accounting graduates, including self-employment, employment in the private and public sectors, and entering public practice with accounting firms.

SAICA has a competency framework that encapsulates the specific competencies for an entry-level chartered accountant. The International Federation of Accountants (IFAC), a global accounting body, through its education committee, also seeks to instigate the production of competent accounting graduates who have "the ability to perform tasks and roles expected of professional accountants, both newly qualified and experienced, to the standard expected by employers and the general public" (IFAC, 2014, p. 1).

There are many benefits associated with pervasive skills in a professional accounting work context, such as enhancing the application of technical accounting knowledge in situations that are non-routine and complex (Bayerlein \& Timpson, 2017). These skills not only assist newly graduated accounting professionals to apply their university-acquired accounting knowledge but are also beneficial to their smooth transition into the workplace; the transition from the desk to professional life is better facilitated (Jones, 2014). Moreover, Sithole (2015) has suggested that pervasive skills positively influence performance in a work context. In auditing, one of the specialist areas in accounting, pervasive skills are valued because the field requires both emotional and social intelligence (Nadziakiewicz, 2016). Pervasive skills also have an association with the fostering of lifelong learning in accounting graduates (Tan $\&$ Fawzi, 2017), a crucial aspect considering that accounting standards change rapidly and, accordingly, accountants need to keep abreast of the changes.

The roles fulfilled by accounting professionals as engines who drive accounting practices and business today have changed from number crunching to more involved roles such as providing leadership and strategic direction. The changes taking place in the accounting workplace are not merely cosmetic; they are real changes induced by global changes (Maclean \& Ordonez, 2007). Heavy workloads and frequent changes in technology, tax legislation, business systems, and professional standards have all contributed to the changes in the professional lives of accountants and the skills required of them (Smith et al., 2011). These changes present challenges for new entrants who need to understand the accounting 
profession in order to prepare themselves for a successful career in the field. As new entrants, accounting graduates must "shorten the learning curve between 'book knowledge and practical business application"' (Marshall, 2014, p. 2). It has become apparent that, in today's global and digital world of accounting, the role of accounting professionals has been reshaped and so have the skills requirements expected so that new entrants are more work ready. Their roles are critical to improving company performance and to driving strategy and, as framed by HCT (Becker, 1964), are instrumental in achieving increased value and competitive advantage. As key role players in business, they are perceived to be critical sources of organisational performance (Klibi \& Oussii, 2013).

Professional bodies in accounting have expressed the need for accounting graduates to be employment ready in terms of core discipline-specific competencies and pervasive skills (de Villiers, 2010; Helliar, 2013). However, these graduates are not ready to perform accounting tasks without receiving training from their employers, which then questions their readiness (Jackling \& de Lange, 2009; Wells et al., 2009). The technical knowledge of graduates seems to be adequate, but a general lack of non-technical skills frequently surfaces (Bunney et al., 2015; Sithole, 2015; Tempone et al., 2012). Wye \& Lim (2009) pointed out that the hard skills learned at university through various accounting courses are not complemented by the development of pervasive skills, creating a mismatch between what employers expect and what graduates can offer. This affects the accounting graduates' employability and their ability to generate positive output as human capital in the workplace.

Pervasive skills have been proven to have a significant effect on the probability of employment (Cobb-Clark \& Tan, 2011); correspondingly, employers as direct beneficiaries of the skills of graduates, highly value graduates with excellent pervasive skills (Wye \& Lim, 2009). Notably, research has pointed to a link between these skills, development of human capital, and work performance (Crocker \& Eckardt, 2014). Generally, employers require accounting graduates who have been exposed to a rounded education system that has prepared them to be team members and clear communicators who are flexible and emotionally aware (Daff et al., 2012).

Employers expect accounting education, whose overall objective is to develop competent professional accountants (IFAC, 2014; Strauss-Keevy, 2014), to inculcate pervasive skills that will enable graduates to offer the best client service, and to cooperate with others in the workplace (Evenson, 1999). In terms of HCT (Becker, 1964), it is the intangible resources (pervasive skills) that are necessary for the attainment of organisational objectives. In the context of accounting, with the right skills set, an organisation can achieve more when the human capital (accounting graduates) use their skills to share ideas for solving complex financial transactions and for making strategic business decisions for the organisation. Business expects accounting graduates to enhance the entity's economic value and earnings upon entering the workplace. Thus, these graduates are required to perform at their best level. University training and education are the resources graduates use to reach their full potential in a professional space (Kalfa \& Taksa, 2015). With this in mind, the role of ensuring that pervasive skills are instilled remains a task that accounting programmes take seriously 
(Crawford et al., 2011). This task is overseen by professional bodies dedicated to advancing the interest of the profession through an accreditation and review process. As part of this process, accounting education in universities offering SAICA-accredited accounting programmes is expected to explain how the development of pervasive skills by accounting students is addressed in the curriculum (Barac \& du Plessis, 2014).

However, the point often overlooked is that given the intensity of university accounting programmes, which are characterised by challenging academic workloads and a high student failure rate, focusing on all the pervasive skills may prove challenging or even impossible for the academic programme. Academics, in addition to teaching high numbers of students, have to include pervasive skills in their learning outcomes, activities, and assessments. They are also expected to teach, using methods that promote the development of pervasive skills such as group work, educational games, class or group assignments/presentations, simulations, role-play, and problem-based learning activities such as case studies (Keevy, 2016; Reyneke \& Shuttleworth, 2018; Riccio \& Sakata, 2005; Viviers et al., 2016). These approaches, however, work best in classes with small numbers and it can be challenging to find teaching approaches that meet the needs of a diverse group of students with different strengths, preferences, and needs. Moreover, pervasive skills, unlike technical skills, are rarely explicitly assessed and their development may, at times be independent of the formal curriculum (Chamorro et al., 2010). Additionally, the technical orientation of the accounting curriculum can limit the scope for the development of pervasive skills (Low et al., 2013). Another challenge is expanding an already academically demanding and crowded accounting curriculum (Paisey \& Paisey, 2007).

\section{Theoretical framework}

This study adopted human capital theory (HCT) as a theoretical framework to underpin the study. HCT, coined by Gary Becker (1964) in his book Human Capital, has been used in many research studies and fields to understand the value of skills, competencies, and attributes expected by employers from an employee to increase the marketability of the employee as a unit of productivity. The theory provides a way of understanding what makes a unit of productivity more desirable to employers who seek to gain from employees' technical competence and skills in their quest for value creation in the workplace.

The study subscribes to a definition of HCT "as investing in both formal and informal education and training, which provides and enhances individual productivity by providing knowledge, skills and attitude and motivation necessary for economic and social development" (Woodhall, 1985, p. 15). The central proposition of the theory is that people are considered a form of capital for development (Engelbrecht, 2003). Following this thinking, education and development are considered to be deliberate investments that prepare the labour force for its productivity. 


\section{Research methodology}

This study was conducted using a descriptive quantitative research design that is appropriate when the researcher aims to "describe the phenomenon and presents a picture of the specific details of a situation, social setting, or relationship" (Neuman, 2000, p. 22). To determine the preferences of employers when recruiting, a quantitative content analysis of online web-based advertised accounting vacancies was undertaken because advertised job advertisements presumably indicate what employers require from prospective employees. The use of the internet by users and businesses for advertising has increased tremendously due to the number of people it can reach, and its flexibility in terms of accessing information (Lim \& Lau, 2011). Using online vacancies was beneficial in terms of time and cost; however, offcampus network connectivity presented challenges, resulting in a longer data collection period. The use of internet sources for data collection does have disadvantages such as security concerns about the hacking of systems and virus attacks (O'Neill, 2004), and it does not allow for retrospective historical analysis of data because data is only available at a particular time (Kureková et al., 2015). To overcome some of these limitations, anti-virus software was upgraded to the latest version, and data was stored on external drives.

Online advertisements were purposively sampled to ensure coverage of all employment levels, specialisations (financial accounting, auditing, management accounting, and taxation), and sectors of employment (public practice, private sector and public sector). A total of 315 advertisements were collected over 10 months, from January 2019 to October 2019. Job advertisements are under-utilised, current, and publicly accessible data sources (Mathews \& Redman, 2001). In South Africa, it has become a common practice for employers to advertise available positions using web-based or online platforms. Three popular online platforms were used: Careers24 (www.careers24.com), PNet (www.pnet.co.za) and Indeed (www.indeed.co.za). For public sector vacancies, the websites of different government departments were accessed. Preliminary scanning of job advertisements was undertaken to determine the titles and descriptions used because terminology could differ from one job advert to another. Content analysis involved an examination of the exact words in job advertisements, which were thereafter coded into categories.

Data was processed and analysed using SPSS Statistics V.25. Data collected was from all provinces and from various sectors of the economy. The public sector included all spheres of government: national, provincial, and local.

\section{Findings and discussion}

Table 1 is not part of the findings of the study but is provided to illustrate the type of accounting positions sampled. In the 315 sampled accounting vacancies, various job titles were used to describe accounting positions. To shorten the list, similar job titles were combined into categories. These categories were determined in order to group job titles into sub-categories through a process of identifying expected vital terms. For job titles with unexpected or new terms, a separate category was created. 
Table 1: Job titles

\begin{tabular}{|c|c|c|c|c|}
\hline & & Frequency & Valid Percent & $\begin{array}{r}\text { Cumulative } \\
\text { Percent }\end{array}$ \\
\hline \multirow[t]{21}{*}{ Valid } & $\begin{array}{l}\text { Financial accounting and } \\
\text { control manager }\end{array}$ & 2 & 6 & 95.6 \\
\hline & $\begin{array}{l}\text { Asset clerk: Asset } \\
\text { management }\end{array}$ & 3 & 1.0 & 93.7 \\
\hline & $\begin{array}{l}\text { Expenditure analyst: } \\
\text { Provincial government } \\
\text { finance }\end{array}$ & 4 & 1.3 & 94.9 \\
\hline & $\begin{array}{l}\text { Assistant financial } \\
\text { accountant: Finance }\end{array}$ & 6 & 1.9 & 97.5 \\
\hline & $\begin{array}{l}\text { Fixed assets clerk: } \\
\text { Finance }\end{array}$ & 6 & 1.9 & 92.7 \\
\hline & Trainee accountant & 8 & 2.5 & 100.0 \\
\hline & Bookkeeper & 12 & 3.8 & 68.9 \\
\hline & Finance officer & 12 & 3.8 & 86.3 \\
\hline & Tax accountant & 12 & 3.8 & 65.1 \\
\hline & Chief financial officer & 14 & 4.4 & 90.8 \\
\hline & Financial controller & 15 & 4.8 & 41.9 \\
\hline & Financial analyst & 17 & 5.4 & 82.5 \\
\hline & Article clerk & 18 & 5.7 & 5.7 \\
\hline & Company accountant & 19 & 6.0 & 21.6 \\
\hline & Management accountant & 20 & 6.3 & 27.9 \\
\hline & Senior accountant & 26 & 8.3 & 77.1 \\
\hline & Assistant accountant & 29 & 9.2 & 51.1 \\
\hline & Graduate accountant & 29 & 9.2 & 37.1 \\
\hline & Accountant & 31 & 9.9 & 15.6 \\
\hline & Internal auditor & 32 & 10.2 & 61.3 \\
\hline & Total & 315 & 100.0 & \\
\hline
\end{tabular}

Table 2 reveals the different terminology used by employers in advertised accounting vacancies, synonymous with what this study refers to as pervasive skills.

Table 2: Terms used for "pervasive skills"

\begin{tabular}{|l|l|r|r|r|}
\hline \multicolumn{2}{|c|}{} & Frequency & $\begin{array}{r}\text { Valid } \\
\text { Percent }\end{array}$ & $\begin{array}{r}\text { Cumulative } \\
\text { Percent }\end{array}$ \\
\hline \multirow{4}{*}{ Valid } & Total & 315 & 100.0 & \\
\cline { 2 - 5 } & No soft skills on the advert & 83 & 26.3 & 57.1 \\
\cline { 2 - 5 } & Recommended skills & 63 & 20.0 & 88.6 \\
\cline { 2 - 5 } & Critical skills & 39 & 12.4 & 19.4 \\
\cline { 2 - 5 } & Personal skills & 12 & 3.8 & 68.6 \\
\cline { 2 - 5 } & Other skills & 12 & 3.8 & 61.0 \\
\cline { 2 - 5 } & Skills & 11 & 3.5 & 93.7 \\
\hline
\end{tabular}




\begin{tabular}{|c|c|c|c|}
\hline Soft skills & 10 & 3.2 & 100.0 \\
\hline Key skills & 10 & 3.2 & 30.8 \\
\hline Desired skills & 9 & 2.9 & 22.5 \\
\hline Skills and abilities & 6 & 1.9 & 95.6 \\
\hline Competencies & 6 & 1.9 & 5.7 \\
\hline Personal qualities & 5 & 1.6 & 64.8 \\
\hline Required skills & 5 & 1.6 & 90.2 \\
\hline Key competencies & 5 & 1.6 & 27.6 \\
\hline Personal competencies & 5 & 1.6 & 63.2 \\
\hline Skills and behaviours & 4 & 1.3 & 96.8 \\
\hline Behavioural competencies & 4 & 1.3 & 2.9 \\
\hline Expected skills & 4 & 1.3 & 23.8 \\
\hline Generic skills & 4 & 1.3 & 25.7 \\
\hline Additional skills & 3 & 1.0 & 1.6 \\
\hline Criteria skills & 2 & .6 & 7.0 \\
\hline Behaviours & 2 & .6 & 3.8 \\
\hline Additional requirements & 2 & .6 & .6 \\
\hline Core skills & 2 & .6 & 6.3 \\
\hline Desired behavioural skill & 1 & .3 & 19.7 \\
\hline Important skills & 1 & .3 & 26.0 \\
\hline Personal characteristics & 1 & .3 & 61.6 \\
\hline Generic competencies & 1 & .3 & 24.4 \\
\hline Behavioural skills & 1 & .3 & 3.2 \\
\hline Extra skills & 1 & .3 & 24.1 \\
\hline People skills & 1 & .3 & 61.3 \\
\hline
\end{tabular}

It appears that employers use a variety of terms, some commonly used, and others not as clearly descriptive of pervasive skills. In $20 \%$ of the cases, these skills are referred to as "recommended skills," suggesting that they are preferred by employers, and confirming findings that pervasive skills are important for a career in accounting (Helliar et al., 2009; Nadziakiewicz, 2016). This also confirms the recognition of the importance of these skills by accounting bodies (American Institute of Certified Public Accountants, 2005; IFAC, 2014). Some terms, however, could misleadingly suggest to the graduate that the skills are not as important, for example, "extra skills" and "additional skills." Other terms did highlight their significance, such as "core skills," "desired skills," "key skills," and "critical skills." It was noted that $12.4 \%$ of employers referred to these skills as critical skills, implying that an accountant must be in possession of these skills. Then again, $26.3 \%$ of advertisements did not indicate any pervasive skills, a result open to different interpretations. It could be that employers evaluate whether prospective employees have the desired skills during other recruitment stages, for example, during the interview phase or the probation period. Another interpretation, unfortunately, paints a bleak picture: that employers of accounting graduates are not expecting prospective employees to demonstrate pervasive skills, suggesting they are 
mere add-ons or nice-to-haves, and furthering the ongoing soft skills/hard skills debate. This contradicts de Lange et al. (2006), who argued that career success in accounting depends not just on technical competence but on personal characteristics. Furthermore, other studies have argued that long-term success in the workplace is only influenced by $25 \%$ of technical knowledge $-75 \%$ is dependent on people skills (Klaus 2010), a core component of pervasive skills that is linked to good customer service, which is much needed in all service professions for achieving competitive advantage and returns through human capital (James \& James, 2004). On a more positive note, the results revealed that $73.7 \%$ of employers called for pervasive skills, supporting HCT, which sees employees as necessary assets with intangible resources (their skills) necessary for achieving the best output. In the accounting context, output is quality, timely, and relevant financial reports for making strategic financial decisions that can enhance the earnings value for the organisation.

\section{Pervasive skills most sought after by employers in advertised accounting vacancies}

Table 3 reports the frequency of appearance of the selected pervasive skills in the sampled accounting vacancies. A total of 1,181 pervasive skills were identified in the 315 accounting vacancies, revealing that employers called for more than one pervasive skill in a single advertisement.

Table 3: Pervasive skills: Frequency of appearance

\begin{tabular}{|c|c|c|c|c|}
\hline & & \multicolumn{2}{|c|}{ Responses } & \multirow{2}{*}{$\begin{array}{r}\text { Percent of } \\
\text { Cases }\end{array}$} \\
\hline & & $\mathrm{N}$ & Percent & \\
\hline \multirow[t]{15}{*}{ Pervasive skills in adverts } & Self-management & 12 & $1.0 \%$ & $5.2 \%$ \\
\hline & Time management & 78 & $6.6 \%$ & $33.8 \%$ \\
\hline & Self-discipline & 29 & $2.4 \%$ & $12.6 \%$ \\
\hline & Independence & 53 & $4.5 \%$ & $22.9 \%$ \\
\hline & Oral communication & 211 & $17.9 \%$ & $91.3 \%$ \\
\hline & Written communication & 146 & $12.4 \%$ & $63.2 \%$ \\
\hline & Critical thinking & 143 & $12.1 \%$ & $61.9 \%$ \\
\hline & Decision making & 74 & $6.3 \%$ & $32.0 \%$ \\
\hline & Computer application & 136 & $11.5 \%$ & $58.9 \%$ \\
\hline & Teamwork & 65 & $5.5 \%$ & $28.1 \%$ \\
\hline & Stress management & 48 & $4.0 \%$ & $20.8 \%$ \\
\hline & Problem solving & 86 & $7.3 \%$ & $37.2 \%$ \\
\hline & Lifelong learning & 27 & $2.3 \%$ & $11.7 \%$ \\
\hline & Responsibility & 32 & $2.7 \%$ & $13.9 \%$ \\
\hline & Numeracy & 41 & $3.5 \%$ & $17.7 \%$ \\
\hline \multicolumn{2}{|l|}{ Total } & 1181 & $100.0 \%$ & \\
\hline
\end{tabular}


The findings in Table 3 reveal that the most sought after pervasive skill, oral communication, featured as a job requirement or recommendation in $91.3 \%$ of cases. That was followed by written communication, appearing in $63.2 \%$ of advertisements and critical thinking $(61.9 \%)$, suggesting that communication skills are essential for securing accounting-related employment-supporting HCT, which suggests that communication skills are essential for business growth (Holmberg-Wright \& Hribar, 2016). This is in line with the position held by various other scholars in accounting (Barratt et al., 2011; Camacho, 2015; Hancock et al., 2009) who have reported that communication skills are crucial for an accounting career. Also in support of these findings, is an argument that, given the level of involvement and interaction with other parties inside and outside the organisation, communication skills are must-haves for accountants (Geertshuis et al., 2015). The results confirm that oral communication skills are considered essential by employers of accounting professionals because new accountants spend an average of six hours per week communicating orally with colleagues, clients, and superiors (Gray, 2010). And the results are in agreement that written communication is critical particularly, grammar, punctuation, spelling, and language clarity (Riley \& Simons, 2016), given the roles of accountants who write reports to explain how money was budgeted and expended. Dale-Jones et al. (2013) concurred, quoting the International Accounting Education Standards Board, IES 3, which stated: "Professional accountants are expected to be able to present, discuss, report and defend views effectively through formal, informal, written and spoken communication" (IFAC, 2014, p. 5). Furthermore, the high level of communication and interaction between accounting practitioners, clients, accountants, and management is crucial to maintain the stability of the company (Cobo, 2013; Viviers, 2016b), which is necessary for its growth and success.

The findings of this study are in agreement with Aldhizer III (2015), who pointed out that, in audit environments, it is essential to have critical thinking skills, especially when debriefing clients and audit partners about financial risks determined. The results confirm human capital as the value provided by employees who critically apply their knowledge and skills in the workplace (Holmberg-Wright \& Hribar, 2016). The findings also support Stoner and Milner (2010), who suggested that generic employability skills relevant to the employability of accounting graduates include critical thinking. And they endorse the move by many accredited universities in South Africa, from theoretical learning to a more applied form of learning (Hart Research Associates, 2015).

\section{Employers' calls for pervasive skills according to the level of employment}

Table 4 shows the frequency of call for the selected pervasive skills per level of employment-from entry-level accounting positions to upper management level. In this study, the following criteria were used to distinguish between the different levels:

Entry:

- Relevant accounting qualification 
- 0-3 years of related work experience.

\section{Supervisory:}

- 3-6 years of relevant work experience

- Relevant qualification.

Upper:

- Postgraduate level qualification

- Experience-6 years and more.

Table 4: Pervasive skills per job level

\begin{tabular}{|c|c|c|c|c|c|c|}
\hline & & & & b level & & Total \\
\hline & & & Entry & $\begin{array}{l}\text { Super- } \\
\text { visory }\end{array}$ & Upper & \\
\hline Pervasive & Self-management & Count & 5 & 3 & 4 & 12 \\
\hline adverts & & $\%$ within level & $4.0 \%$ & $4.5 \%$ & $10.3 \%$ & \\
\hline & Time management & Count & 33 & 26 & 19 & 78 \\
\hline & & $\%$ within level & $26.2 \%$ & $39.4 \%$ & $48.7 \%$ & \\
\hline & Self-discipline & Count & 18 & 8 & 3 & 29 \\
\hline & & $\%$ within level & $14.3 \%$ & $12.1 \%$ & $7.7 \%$ & \\
\hline & Independence & Count & 24 & 17 & 12 & 53 \\
\hline & & $\%$ within level & $19.0 \%$ & $25.8 \%$ & $30.8 \%$ & \\
\hline & Oral & Count & 114 & 60 & 37 & 211 \\
\hline & & $\%$ within level & $90.5 \%$ & $90.9 \%$ & $94.9 \%$ & \\
\hline & Written & Count & 75 & 47 & 24 & 146 \\
\hline & & $\%$ within level & $59.5 \%$ & $71.2 \%$ & $61.5 \%$ & \\
\hline & Critical thinking & Count & 68 & 45 & 30 & 143 \\
\hline & & $\%$ within level & $54.0 \%$ & $68.2 \%$ & $76.9 \%$ & \\
\hline & Decision making & Count & 44 & 21 & 9 & 74 \\
\hline & & $\%$ within level & $34.9 \%$ & $31.8 \%$ & $23.1 \%$ & \\
\hline & Computer & Count & 69 & 40 & 27 & 136 \\
\hline & & $\%$ within level & $54.8 \%$ & $60.6 \%$ & $69.2 \%$ & \\
\hline & Teamwork & Count & 23 & 31 & 11 & 65 \\
\hline & & $\%$ within level & $18.3 \%$ & $47.0 \%$ & $28.2 \%$ & \\
\hline & Stress management & Count & 20 & 11 & 17 & 48 \\
\hline & & $\%$ within level & $15.9 \%$ & $16.7 \%$ & $43.6 \%$ & \\
\hline & Problem-solving & Count & 43 & 22 & 21 & 86 \\
\hline & & $\%$ within level & $34.1 \%$ & $33.3 \%$ & $53.8 \%$ & \\
\hline & Lifelong learning & Count & 11 & 10 & 6 & 27 \\
\hline & & $\%$ within level & $8.7 \%$ & $15.2 \%$ & $15.4 \%$ & \\
\hline
\end{tabular}




\begin{tabular}{|l|l|l|r|r|r|r|}
\hline \multirow{2}{*}{} & Responsibility & Count & 17 & 9 & 6 & 32 \\
\cline { 3 - 7 } & & $\%$ within level & $13.5 \%$ & $13.6 \%$ & $15.4 \%$ & \\
\cline { 2 - 7 } & \multirow{2}{*}{ Numeracy } & Count & 25 & 12 & 4 & 41 \\
\cline { 3 - 7 } & & $\%$ within level & $19.8 \%$ & $18.2 \%$ & $10.3 \%$ & \\
\hline
\end{tabular}

The results did not show much difference when analysed per experience level, except for critical thinking. Oral communication appeared to be consistently desired across all three job levels. The findings are consistent with those of (Hussein, 2017), who identified communication skills as one of the five factors of importance for accounting graduates. It was interesting to note that critical thinking seemed to be preferred more as levels increased (54\% at entry, $68.2 \%$ supervisory, $76.9 \%$ upper). In upper management, accountants are more likely to deal with strategic, complex, and non-routine transactions than at entry-level where financial transactions are likely to be clerical. As Bunney et al. (2015) stated, with the changes taking place in accounting, there is a greater need for communication and critical thinking skills.

\section{Employers' calls for pervasive skills in the different sectors of employment}

Table 5 displays the skills that employers of accounting graduates called for in accounting vacancies in the different employment sectors, public practice, private sector, and public sector.

Table 5: Pervasive skills per sector of employment

\begin{tabular}{|c|c|c|c|c|c|c|}
\hline & & & & ector & & Total \\
\hline & & & $\begin{array}{l}\text { Public } \\
\text { Practice }\end{array}$ & Private & Public & \\
\hline Pervasive & Self-management & Count & 1 & 9 & 2 & 12 \\
\hline & & $\%$ within sector & $3.4 \%$ & $6.3 \%$ & $3.4 \%$ & \\
\hline & Time management & Count & 7 & 49 & 22 & 78 \\
\hline & & $\%$ within sector & $24.1 \%$ & $34.3 \%$ & $37.3 \%$ & \\
\hline & Self-discipline & Count & 2 & 18 & 9 & 29 \\
\hline & & $\%$ within sector & $6.9 \%$ & $12.6 \%$ & $15.3 \%$ & \\
\hline & Independence & Count & 9 & 33 & 11 & 53 \\
\hline & & $\%$ within sector & $31.0 \%$ & $23.1 \%$ & $18.6 \%$ & \\
\hline & Oral communication & Count & 25 & 129 & 57 & 211 \\
\hline & & $\%$ within sector & $86.2 \%$ & $90.2 \%$ & $96.6 \%$ & \\
\hline & Written & Count & 21 & 88 & 37 & 146 \\
\hline & Communication & $\%$ within sector & $72.4 \%$ & $61.5 \%$ & $62.7 \%$ & \\
\hline & Critical thinking & Count & 16 & 82 & 45 & 143 \\
\hline & & $\%$ within sector & $55.2 \%$ & $57.3 \%$ & $76.3 \%$ & \\
\hline & Decision making & Count & 5 & 41 & 28 & 74 \\
\hline & & $\%$ within sector & $17.2 \%$ & $28.7 \%$ & $47.5 \%$ & \\
\hline
\end{tabular}




\begin{tabular}{|c|c|c|c|c|c|}
\hline \multirow{2}{*}{$\begin{array}{l}\text { Computer } \\
\text { application }\end{array}$} & Count & 22 & 83 & 31 & 136 \\
\hline & $\%$ within sector & $75.9 \%$ & $58.0 \%$ & $52.5 \%$ & \\
\hline \multirow[t]{2}{*}{ Teamwork } & Count & 4 & 42 & 19 & 65 \\
\hline & $\%$ within sector & $13.8 \%$ & $29.4 \%$ & $32.2 \%$ & \\
\hline \multirow[t]{2}{*}{ Stress management } & Count & 3 & 24 & 21 & 48 \\
\hline & $\%$ within sector & $10.3 \%$ & $16.8 \%$ & $35.6 \%$ & \\
\hline \multirow[t]{2}{*}{ Problem-solving } & Count & 12 & 56 & 18 & 86 \\
\hline & $\%$ within sector & $41.4 \%$ & $39.2 \%$ & $30.5 \%$ & \\
\hline \multirow[t]{2}{*}{ Lifelong learning } & Count & 2 & 17 & 8 & 27 \\
\hline & $\%$ within sector & $6.9 \%$ & $11.9 \%$ & $13.6 \%$ & \\
\hline \multirow[t]{2}{*}{ Responsibility } & Count & 6 & 21 & 5 & 32 \\
\hline & $\%$ within sector & $20.7 \%$ & $14.7 \%$ & $8.5 \%$ & \\
\hline \multirow[t]{2}{*}{ Numeracy } & Count & 0 & 30 & 11 & 41 \\
\hline & $\%$ within sector & $0.0 \%$ & $21.0 \%$ & $18.6 \%$ & \\
\hline
\end{tabular}

The findings reveal that oral communication maintained its status irrespective of the sector of employment $(86.2 \%, 90.2 \%, 96.6 \%)$. Written communication showed a marginal variation but remained high in public practice employment. In public practice, accountants are involved in audits and are expected to be able to communicate with clients (Hesketh, 2011). Critical thinking is the third-most desired pervasive skill, particularly in the public sector (76.3\%). This finding is consistent with an argument that accountants should demonstrate these skills through an ability to examine issues, theorise, consider options to accounting problems, and provide creative solutions when dealing with complex client issues (Gardner, 2017). Their ability to offer practicable and creative accounting solutions creates value for the accounting practice and the employer benefits from the human capital, which increases its chances of success (Holmberg-Wright \& Hribar, 2016). Surprisingly, critical thinking skills were identified in only $55.2 \%$ of public practice vacancies. This finding was unexpected given the nature of work in public practice, mainly audits, which require a fair amount of critical thinking. More so, "critical thinking influences the formation and strength of auditors' sceptical attitudes" (Nolder \& Kadous, 2018 p. 4), a critical factor when conducting audits. Critical thinking is a skill that supports the application of professional scepticism by auditors because they ought to dig deeper and cannot take information at face value (Karr, 2009). If critical thinking is lacking in the audit human capital, audits will not meet the quality standards and that would negatively affect the audit firm's ability to create economic value.

\section{Employers' calls for other skills and attributes}

Table 6 displays the other skills and attributes that employers of accounting graduates called for in advertised accounting vacancies. "Other skills and attributes" relate to skills and attributes that were outside the perimeters of the list of pervasive skills under investigation. 
Table 6: Other skills and attributes

\begin{tabular}{|c|c|c|c|c|}
\hline & & Frequency & Valid Percent & $\begin{array}{r}\text { Cumulative } \\
\text { Percent }\end{array}$ \\
\hline \multirow[t]{25}{*}{ Valid } & Total & 315 & 100.0 & \\
\hline & $\begin{array}{l}\text { No additional } \\
\text { skills/attributes }\end{array}$ & 79 & 25.1 & 73.7 \\
\hline & Motivation & 34 & 10.8 & 48.6 \\
\hline & $\begin{array}{l}\text { Ability to work under } \\
\text { pressure }\end{array}$ & 31 & 9.8 & 10.8 \\
\hline & People management & 23 & 7.3 & 81.9 \\
\hline & Creative thinking & 20 & 6.3 & 26.7 \\
\hline & Resilience & 17 & 5.4 & 94.0 \\
\hline & Training & 13 & 4.1 & 100.0 \\
\hline & Conflict management & 11 & 3.5 & 20.3 \\
\hline & Leadership & 10 & 3.2 & 37.8 \\
\hline & Emotional intelligence & 10 & 3.2 & 29.8 \\
\hline & Positive & 10 & 3.2 & 87.3 \\
\hline & Business ethics/integrity & 9 & 2.8 & 16.5 \\
\hline & Friendly & 8 & 2.5 & 34.6 \\
\hline & Persistence & 7 & 2.2 & 84.1 \\
\hline & Strategic & 6 & 1.9 & 95.9 \\
\hline & Approachable & 6 & 1.9 & 12.7 \\
\hline & Empathetic & 6 & 1.9 & 31.7 \\
\hline & Ability to discipline & 3 & 1.0 & 1.0 \\
\hline & Patience & 3 & 1.0 & 74.6 \\
\hline & Research & 3 & 1.0 & 88.6 \\
\hline & Business acumen & 3 & 1.0 & 13.7 \\
\hline & Confidence & 1 & .3 & 16.8 \\
\hline & Energetic & 1 & .3 & 32.1 \\
\hline & Recruitment abilities & 1 & .3 & 87.6 \\
\hline
\end{tabular}

These findings show that employers are evidently seeking more than just the ability to balance financial records from an accountant. Some of the desired qualities in these results are qualities that would not typically be associated with an accountant, for example, the ability to motivate others (10.8\%) — banishing stereotypes that accountants are anti-social and unapproachable. Other more outgoing attributes include emotional intelligence, showing that accountants should be able to understand other peoples' emotions (Daff et al., 2012) as a critical requirement in today's active role of an accountant. Overall, the results confirm that business wealth and success depend on the entity's ability to recruit the right human capital with pervasive skills. 


\section{Conclusion}

The findings of this study confirm accounting literature that revealed that employers of accounting graduates are seeking more than just technical skills from their accounting professionals. The employers' calls for pervasive skills supports the central premise of HCT and that employees with high levels of skills attained through education and training are believed to be more productive and hence preferred by employers than those without these skills. The results strongly suggest that investing in the pervasive skills most sought after by employers in addition to technical knowledge, may prove beneficial to accounting education and students/graduates. By prioritising the pervasive skills most sought after, accounting education would achieve its mandate to produce accounting graduates who are employable, work-ready, and meet the expectations of employers - the employability of accounting graduates would be enhanced. Employers would benefit from the growth in human capital, resulting in higher returns, and that positively contributes to economic growth. This study has demonstrated the central role given by employers to oral and written communication and critical thinking, a finding consistent with similar studies in accounting on this topic.

This paper, through its findings, contributes to the existing body of knowledge on the role of pervasive skills in accounting. It hopes to inform and transform the behavioural and educational choices of accounting academics and students through providing evidence about the preferences of employers in terms of non-technical skills of accounting graduates, who, in terms of HCT, are tools for creating added economic value in the organisations they work for. These employer requirements should serve as a guide when prioritising skills in the accounting degree curricula, which would be in line with HCT, which perceives education as an economic activity that produces skills, and knowledge utilised in economic activity.

This study had a limitation due to the data collection method adopted. In general, the recruitment strategies of organisations vary, with some employers advertising in both online platforms and printed media while some opt for printed media only. Therefore, the use of an online platform to collect data would have excluded employers using only printed media to advertise accounting vacancies.

\section{References}

Abayadeera, N., \& Watty, K. (2014). The expectation-performance gap in generic skills in accounting graduates: Evidence from Sri Lanka. Asian Review of Accounting, 22(1), $56-72$.

Aldhizer III, G. R. (2015). Small firm audit partner hiring crisis: A role play for critical thinking and negotiation skills. Issues in Accounting Education, 30(4), 275-296.

Altrawneh, G. A. (2016). An empirical evaluation of accounting graduates' employability skills from Jordanian employers' perspective. International Business Research, 9(1), $55-65$. 
Aman, M., \& Sitotaw, M. (2014). Perception of summer cooperative graduates on employers generic skills preference, Haramaya University, Ethiopia. International Journal of Instruction, 7(2), 181-190.

American Institute of Certified Public Accountants. (2005). Core competency framework and educational competency assessment.

https://www.aicpa.org/interestareas/accountingeducation/resources/corecompetency. html

Barac, K., \& du Plessis, L. (2014). Teaching pervasive skills to South African accounting students. Southern African Business Review, 18(1), 53-79.

Barratt, C., Hanlon, D., \& Rankin, M. (2011). Assessing the success of a discipline-based communication skills development and enhancement program in a graduate accounting course. Higher Education Research \& Development, 30(6), 681-695.

Bayerlein, L., \& Timpson, M. (2017). Do accredited undergraduate accounting programmes in Australia meet the needs and expectations of the accounting profession?

Education+ Training, 59(3), 305-322.

Becker, G. (1964). Human capital: A theoretical and empirical analysis, with special reference to education. University of Chicago Press.

Boyce, G., Williams, S., Kelly, A., \& Yee, H. (2001). Fostering deep and elaborative learning and generic (soft) skill development: The strategic use of case studies in accounting education. Accounting Education, 10(1), 37-60.

Bunney, D., Sharplin, E., \& Howitt, C. (2015). Generic skills for graduate accountants: The bigger picture, a social and economic imperative in the new knowledge economy. Higher Education Research \& Development, 34(2), 256-269.

Camacho, L. (2015). The communication skills accounting firms desire in new hires. Journal of Business \& Finance Librarianship, 20(4), 318-329.

Chamorro-Premuzic, T., Arteche, A., Bremner, A. J., Greven, C., \& Furnham, A. (2010). Soft skills in higher education: Importance and improvement ratings as a function of individual differences and academic performance. Educational Psychology, 30(2), 221-241.

Cobb-Clark, D. A., \& Tan, M. (2011). Noncognitive skills, occupational attainment, and relative wages. Labour Economics, 18(1), 1-13.

Cobo, C. (2013). Skills for innovation: Envisioning an education that prepares for the changing world. Curriculum Journal, 24(1), 67-85. 
Cory, S. N., \& Pruske, K. A. (2012). Necessary skills for accounting graduates: An exploratory study to determine what the profession wants. ASBBS Proceedings, 19(1), 208-218.

Crawford, L., Helliar, C., \& Monk, E. A. (2011). Generic skills in audit education. Accounting Education: An International Journal, 20(2), 115-131.

Crocker, A., \& Eckardt, R. (2014). A multilevel investigation of individual- and unit-level human capital complementarities. Journal of Management, 40(2), 509-530.

Daff, L., de Lange, P., \& Jackling, B. (2012). A comparison of generic skills and emotional intelligence in accounting education. Issues in Accounting Education, 27(3), 627-645.

Dale-Jones, G., Hancock, P., \& Willey, K. (2013). Accounting students in an Australian university improve their writing: But how did it happen? Accounting Education, 22(6), 544-562.

de Lange, P., Jackling, B., \& Gut, A. M. (2006). Accounting graduates' perceptions of skills emphasis in undergraduate courses: An investigation from two Victorian universities. Accounting \& Finance, 46(3), 365-386.

de Villiers, R. (2010). The incorporation of soft skills into accounting curricula: Preparing accounting graduates for their unpredictable futures. Meditari Accountancy Research, $18(2), 1-22$.

Dunbar, K., Laing, G., \& Wynder, M. (2016). A content analysis of accounting job advertisements: Skill requirements for graduates. e-Journal of Business Education and Scholarship of Teaching, 10(1), 58-72.

Engelbrecht, H. J. (2003). Human capital and economic growth: Cross-section evidence for OECD countries. Economic Record, 79(S.I), S40-S51.

Evenson, R. (1999). Soft skills, hard sell. Techniques: Making Education \& Career Connections, 74(3), 29-31.

Gardner, T. A. (2017). Exploring the importance of soft skills training for accountants [Unpublished doctoral thesis]. Walden University, Minneapolis.

Geertshuis, S. A., Morrison, R. L., \& Cooper-Thomas, H. D. (2015). It's not what you say, it's the way that you say it: The mediating effect of upward influencing communications on the relationship between leader-member exchange and performance ratings. International Journal of Business Communication, 52(2), 228245.

Gibb, S. (2014). Soft skills assessment: Theory development and the research agenda. International Journal of Lifelong Education, 33(4), 455-471. 
Gray, F. E. (2010). Specific oral communication skills desired in new accountancy graduates. Business Communication Quarterly, 73(1), 40-67.

Hakim, R. R. C. (2016). Are accounting graduates prepared for their careers? A comparison of employees' and employers' perceptions. Global Review of Accounting and Finance, 7(2), 1-17.

Hancock, P., Howieson, B., Kavanagh, M., Kent, J., Tempone, I., \& Segal, N. (2009). Accounting for the future: More than numbers. A collaborative investigation into the changing skill set for professional accounting graduates over the next ten years and strategies for embedding such skills into professional accounting programs. Employment and Workplace Relations, 1(1), 1-80.

Hart Research Associates. (2015). Falling short? College learning and career success: Selected findings from online surveys of employers and college students. Association of American Colleges and Universities. https://www.aacu.org/sites/default/files/files/LEAP/2015employerstudentsurvey.pdf

Helliar, C. (2013). The global challenge for accounting education. Accounting Education, 22(6), 510-521.

Helliar, C. V., Monk, E. A., \& Stevenson, L. A. (2009). The development of trainee auditors' skills in tertiary education. International Journal of Auditing, 13(3), 185-202.

Hesketh, J. (2011). Accounting academics' multiple challenges: Issues-driven learning offers a way forward. South African Journal of Accounting Research, 25(1), 1-34.

Holmberg-Wright, K., \& Hribar, T. (2016). Soft skills: The missing piece for entrepreneurs to grow a business. American Journal of Management, 16(1), 11-18.

Hussein, A. (2017). Importance of generic skills in accounting education: Evidence from Egypt. International Journal of Accounting and Financial Reporting, 7(2), 16-35.

International Federation of Accountants (IFAC). (2014). IES 3: Initial professional development-professional skills (revised). https://www.iaesb.org/publications/ies-3initial-professional-development-professional-skills-revised-0

Jackling, B., \& de Lange, P. (2009). Do accounting graduates' skills meet the expectations of employers? A matter of convergence or divergence. Accounting Education: An International Journal, 18(4/5), 369-385.

Jackson, D. (2013). Business graduate employability: Where are we going wrong? Higher Education Research \& Development, 32(5), 776-790.

Jackson, D., \& Chapman, E. (2012). Non-technical skill gaps in Australian business graduates. Education+ Training,54(2/3), 95-113. 
James, R., \& James, M. (2004). Teaching career and technical skills in a "mini”" business world. Business Education Forum, 59(2), 39-41.

Jeacle, I. (2008). Beyond the boring grey: The construction of the colourful accountant. Critical Perspectives on Accounting, 19(8), 1296-1320.

Jones, R. (2014). Bridging the gap: Engaging in scholarship with accountancy employers to enhance understanding of skills development and employability. Accounting Education, 23(6), 527-541.

Kalfa, S., \& Taksa, L. (2015). Cultural capital in business higher education: Reconsidering the graduate attributes movement and the focus on employability. Studies in Higher Education, 40(4), 580-595.

Karr, S. S. (2009). Critical thinking: A critical strategy for financial executives: As accounting standards become more principles-based and global in nature, emphasizing analysis and creative thinking could lead to greater organizational success. Financial Executive, 25(10), 58-62.

Keevy, M. (2016). Using case studies to transfer soft skills (also known as pervasive skills): Empirical evidence. Meditari Accountancy Research, 24(3), 458-474.

Keevy, M. (2020). Core subjects in accounting academic programmes: Development of pervasive skills. South African Journal of Accounting Research, 34(2), 140-160.

Kirstein, M. (2017). Differences in accounting students' perceptions of their development of generic skills and emotional intelligence in a heterogeneous classroom [Unpublished master's thesis]. University of Pretoria, South Africa.

Klibi, M. F., \& Oussii, A. A. (2013). Skills and attributes needed for success in accounting career: Do employers' expectations fit with students' perceptions? Evidence from Tunisia. International Journal of Business and management, 8(8), 118-132.

Kunz, R., \& de Jager, H. (2019). Performance of newly employed trainee accountants in Gauteng, South Africa, versus the skills expectations of employers: How big is the gap? Industry and Higher Education, 33(5), 340-349.

Kureková, L. M., Beblavý, M., \& Thum-Thysen, A. (2015). Using online vacancies and web surveys to analyse the labour market: a methodological inquiry. IZA Journal of Labor Economics, 4(1), 18-38.

Lim, Y., \& Lau, T. (2011). The effectiveness of online advertising in purchase decision: Liking, recall and click. Australian Journal of Basic and Applied Sciences, 5(9), 1517-1524. 
Low, M., Samkin, G., \& Liu, C. (2013). Accounting education and the provision of soft skills: Implications of the recent NZICA CA Academic requirement changes. $e$ Journal of Business Education and Scholarship of Teaching, 7(1), 1-33.

Maclean, R., \& Ordonez, V. (2007). Work, skills development for employability and education for sustainable development. Educational Research for Policy and Practice, 6(2), 123-140.

Marshall, N. (2014). Special Report: Employees. Accountancy SA. https://www.accountancysa.org.za/special-report-employees/

Mathews, B. P., \& Redman, T. (2001). Recruiting the wrong salespeople: Are the job ads to blame? Industrial Marketing Management, 30(7), 541-550.

Mohamed, E. K., \& Lashine, S. H. (2003). Accounting knowledge and skills and the challenges of a global business environment. Managerial finance, 29(7), 3-16.

Nadziakiewicz, M. (2016). The role of soft skills in decision making by auditors. Zeszyty Naukowe: Organizacja i Zarządzanie/Politechnika Śląska, 1958(1), 151-159.

Neuman, W. (2000). Social research methods: Qualitative and quantitative approaches (4th ed.) Allyn \& Baron.

Nolder, C. J., \& Kadous, K. (2018). Grounding the professional skepticism construct in mindset and attitude theory: A way forward. Accounting, Organizations and Society, 67, 1-14.

O’Neill, B. (2004). Collecting research data online: Implications for extension professionals. Journal of Extension, 42(3). https://www.joe.org/joe/2004june/tt1.php

Paisey, C., \& Paisey, N. J. (2007). Balancing the vocational and academic dimensions of accounting education: The case for a core curriculum. Journal of Vocational Education \& Training, 59(1), 89-105.

Ramlall, S., \& Ramlall, D. (2014). The value of soft-skills in the accounting profession: Perspectives of current accounting students. Advances in Research, 2(11), 645-654.

Reyneke, Y., \& Shuttleworth, C. C. (2018). Accounting education in an open distance learning environment: Case studies for pervasive skills enhancement. Turkish Online Journal of Distance Education, 19(3), 140-155.

Riccio, E. L., \& Sakata, M. C. G. (2005). Teaching-learning methods in accounting education: An empirical research in the Brazilian scenario. https://www.dphu.org/uploads/attachements/books/books_3519_0.pdf

Riley, T. J., \& Simons, K. A. (2016). The written communication skills that matter most for accountants. Accounting Education, 25(3), 239-255. 
Schulz, B. (2008). The importance of soft skills: Education beyond academic knowledge. Nawa Journal of Communication 2(1), 146-154

Seetha, N. (2014). Are soft skills important in the workplace? A preliminary investigation in Malaysia. International Journal of Academic Research in Business and Social Sciences, 4(4), 44-56.

Singh, P., Thambusamy, R. X., \& Ramly, M. A. (2014). Fit or unfit? Perspectives of employers and university instructors of graduates' generic skills. Procedia-Social and Behavioral Sciences, 123, 315-324.

Sithole, S. (2015). Quality in accounting graduates: Employer expectations of the graduate skills in the Bachelor of Accounting degree. European Scientific Journal, 11(22), $165-180$.

Smith, K. T., Smith, M., \& Brower, T. R. (2011). An examination of work-life balance perspectives of accountants. International Journal of Critical Accounting, 3(4), 367383.

South African Institute of Chartered Accountants (SAICA). (2009). Competency framework: Competencies of a Chartered Accountant (SA) at entry point to the profession. https://saica.co.za/Portals/0/Documents/CompetencyframeworkCAs.pdf

South African Institute of Chartered Accountants (SAICA). (2010). Professional skills toolkit for trainees.

https://www.saica.co.za/Training/Training/ProfessionalSkillsToolkit/tabid/1751/langu age/en-ZA/Default.aspx

South African Institute of Chartered Accountants (SAICA). (2017). The goal of accounting education and training.

https://www.saica.co.za/Training/Training/tabid/411/language/en-ZA/Default.asp

Stoner, G., \& Milner, M. (2010). Embedding generic employability skills in an accounting degree: Development and impediments. Accounting Education: an international journal, 19(1/2), 123-138.

Strauss-Keevy, M. (2012). Perceptions of accounting academics on the delivery of pervasive skills under the SAICA Competency Framework [Unpublished master's thesis]. University of Johannesburg, South Africa.

Strauss-Keevy, M. (2014). Education programmes' responsibilities regarding pervasive skills. Journal of Economic and Financial Sciences, 7(2), 415-432.

Tan, L. M., \& Fawzi, L. (2017). Employability skills required of accountants. SHS Web of Conferences 34, 06001. http://doi.org/10.1051/shsconf/20173406001 
Tempone, I., Kavanagh, M., Segal, N., Hancock, P., Howieson, B., \& Kent, J. (2012). Desirable generic attributes for accounting graduates into the twenty-first century. Accounting Research Journal, 25(1), 41-55.

van Oordt, T., \& Sullivan, I. (2019). Experiential learning as a method to address the employer expectation gap on pervasive competencies in an undergraduate taxation curriculum [Paper presentation]. Southern African Accounting Association Biennial International Conference, Drakensburg, South Africa. http://www.saaa.org.za/Downloads/Publications/EDU016\%20Experiential\%20learnin $\mathrm{g} \% 20 \mathrm{as} \% 20 \mathrm{a} \% 20$ method $\% 20$ to $\% 20$ address $\% 20$ the $\% 20$ exployer $\% 20$ expectation $\% 20$ gap $\% 20$ on $\% 20$ pervasive $\% 20$ competencies $\% 20 \mathrm{in} \% 20$ an $\% 20$ undergraduate $\% 20$ taxati on\%20curriculum.pdf

Viviers, H. A. (2016a). Taking stock of South African accounting students' pervasive skills development: Are we making progress? South African Journal of Higher Education, 30(2), 242-263.

Viviers, H. A. (2016b). Qualitative evaluation of the design variables of a teaching intervention to expose accounting students to pervasive skills. Industry and Higher Education, 30(6), 402-412.

Viviers, H. A., Fouché, J. P., \& Reitsma, G. M. (2016). Developing soft skills (also known as pervasive skills): Usefulness of an educational game. Meditari Accountancy Research, 24(3), 368-389.

Weber, M. R., Finley, D. A., Crawford, A., \& Rivera Jr, D. (2009). An exploratory study identifying soft skill competencies in entry-level managers. Tourism and Hospitality Research, 9(4), 353-361.

Wells, P., Gerbic, P., Kranenburg, I., \& Bygrave, J. (2009). Professional skills and capabilities of accounting graduates: The New Zealand expectation gap? Accounting Education: An International Journal, 18(4/5), 403-420.

Woodhall, M. (1985). Education for development: An analysis of investment choices. World Bank.

Wye, C.-K., \& Lim, Y. M. (2009). Perception differential between employers and undergraduates on the importance of employability skills. International Education Studies, 2(1), 95-105. 